\title{
Adherence to the objectives of the Safe Surgery Saves Lives Initiative: perspective of nurses*
}

\author{
Larissa de Siqueira Gutierres ${ }^{1}$ \\ José Luís Guedes dos Santos² \\ Sayonara de Fátima Faria Barbosa ${ }^{2}$ \\ Ana Rosete Camargo $\mathrm{Maia}^{2}$ \\ Cintia Koerich ${ }^{2}$ \\ Natalia Gonçalves²
}

\begin{abstract}
Objective: to measure the adherence to the objectives of the Safe Surgery Saves Lives Initiative in surgical centers from the perspective of nurses. Method: cross-sectional study, developed through an online survey via the Google Forms ${ }^{\circledR}$ platform. The study participants were 220 nurses from surgical centers in different regions of Brazil. The data were collected through a socio-professional characterization form and a questionnaire in which the participants indicated their level of agreement in relation to the fulfillment of the objectives of the Safe Surgery Saves Lives Initiative. Data analysis was performed using descriptive statistics. Results: objective 1, The team will operate on the correct patient at the correct site, presented the highest levels of total agreement $(n=144 ; 65.5 \%)$ and partial agreement $(n=52 ; 23.6 \%)$. Objective 10 , Hospitals and the public health systems will establish routine surveillance of surgical capacity, volume and results, obtained the lowest percentages of total ( $n=69,31.4 \%$ ) and partial agreement ( $n=81,36.8 \%)$. Conclusion: adherence to the objectives of the Initiative is adequate, but there are weaknesses, especially in relation to the prevention of never events.

Descriptors: Patient Safety; Surgicenters; Operating Room Nursing; Quality of Health Care; Practice Management; Health Management.
\end{abstract}

\footnotetext{
* Paper extracted from master's thesis "Práticas de enfermeiros na gestão do cuidado de enfermagem para a promoção da segurança do paciente no centro cirúrgico", presented to Universidade Federal de Santa Catarina, Florianópolis, SC, Brazil.

${ }^{1}$ Hospital Baia Sul, Centro Cirúrgico, Florianópolis, SC, Brazil.

2 Universidade Federal de Santa Catarina, Departamento de Enfermagem, Florianópolis, SC, Brazil.
}

\section{How to cite this article}

Gutierres LS, Santos JLG, Barbosa SFF, Maia ARC, Koerich C, Gonçalves N. Adherence to the objectives of the Safe Surgery Saves Lives Initiative: perspective of nurses. Rev. Latino-Am. Enfermagem. 2019;27:e3108. [Access 1 - $]$; Available in: month day year DOI: http://dx.doi.org/10.1590/1518-8345.2711.3108 


\section{Introduction}

Surgical centers are considered to be complex and high-risk units, susceptible to errors and adverse events that can lead to death or complications for patients. In developed countries, the rate of major complications in surgical procedures is $3-16 \%$ and the mortality rate is $0.4-0.8 \%$; approximately half of these events may be considered preventable. In developing countries, mortality rates of 5 to $10 \%$ are estimated in large surgeries ${ }^{(1)}$.

In view of this scenario, in 2009, the World Health Organization (WHO) issued guidelines for the implementation of a universal protocol for the safety of surgical patients. The guideline was developed after the Safe Surgery Saves Lives Initiative and was translated into Brazilian Portuguese by the National Sanitary Surveillance Agency (ANVISA) and released in 2010(1-2).

From this global initiative, the theme has gained broad projection through television media and social networks, widening the debate between specialists, health professionals and patients. The Safe Surgery Saves Lives Initiative ${ }^{(1)}$ aims at reducing the number of deaths and surgical complications and contemplates 10 essential goals to guarantee patient safety. This set of objectives can be considered as a tool for safety in the practice of health professionals, assisting them in the development of actions aimed at reducing errors in care processes $^{(1,3)}$.

The implementation of a patient safety program in a health institution goes beyond the application of questionnaires and achievement of targets. Culture should be included in the mission and values of the health institution and leaders should understand the practice of patient safety as an indicator of quality of care. In this context, nurses are better able to identify the risks to which patients are exposed in the surgical center and, therefore, lead to the incorporation of a safe surgery culture and adherence to the objectives of the Initiative $\mathrm{e}^{(3-5)}$

National and international researchers have highlighted the need for research on how to improve the organizational culture of patient safety and to evaluate the evolution of the implementation of processes for improving surgical care ${ }^{(2-6)}$. However, according to a recent review of publications related to patient safety in the hospital environment, only $3.5 \%$ of the studies approached the subject of safe surgery, especially with regard to adherence and/or patient safety culture among professionals $^{(6)}$. Thus, there is the need to deepen the knowledge about the adherence of health professionals to the Safe Surgery Saves Lives Initiative.

Adherence can be defined as the adoption and maintenance of good practices for quality and patient safety in health services, which requires from the professional technical knowledge, ethical attitude and motivation ${ }^{(7)}$. Thus, considering that surgical center nurses in Brazil are the managers of this sector and have a fundamental position in developing strategies for the safety of the surgical patient, the outlined research question is: How is the adherence of health professionals to the objectives of the Safe Surgery Saves Lives Initiative from the perspective of surgical center nurses?

The objective of the present study was to measure adherence to the objectives of the Safe Surgery Saves Lives Initiative in surgical centers from the perspective of nurses.

\section{Method}

This is a cross-sectional study developed through an online survey for surgical center nurses from different regions of Brazil.

Data collection was performed from June to August 2017 via the Google Forms ${ }^{\circledR}$ platform. The choice of a virtual questionnaire had the objective of maximizing the data collection, since Internet surveys represent an economical alternative that makes it possible to overcome geographical barriers and increase the number of study participants( ${ }^{(8)}$.

For composing the research sample, the link with the questionnaire was sent by e-mail to registered nurses at the Brazilian Society of Surgical Center, Material and Sterilization Center and Post-Anesthetia Recovery (SOBECC in Portuguese) and at the Brazilian Nursing and Patient Safety Network (REBRAENSP in Portuguese). The sending of this e-mail was made directly by the aforementioned entities, and it is not possible to specify the total number of participants enrolled in this stage of the research.

In a complementary manner, the study's main researcher sent 341 e-mails with the questionnaire link to participants of the Brazilian Hospital Network with Patient Safety Center (NSP in Portuguese) registered with the Brazilian Agency of Sanitary Surveillance (ANVISA in Portuguese). The Regional Nursing Councils (CORENs) and the state sections of the Brazilian Nursing Association (ABEN) were also requested to send the questionnaire link to their members. These institutions were chosen for bringing together potential study participants. 
In order to broaden access to research and, therefore, include non-registered nurses in the aforementioned institutions, the research link was also shared for WhatsApp ${ }^{\circledR}$ groups and contacts to which the researchers had access and who were related to work in health/surgical centers. In total, 205 messages were sent via WhatsApp ${ }^{\circledR}$. The link was also shared on social networks, such as Facebook ${ }^{\circledR}$, LinkedIn ${ }^{\circledR}$ and Instagram ${ }^{\circledR}$, reaching more than 23 thousand people, of whom 219 clicked on the link.

Based on these strategies, we sought to include the largest number of nurses working in surgical centers in Brazil. In view of the absence of previous literature to estimate the number of nurses working in surgical centers at a national level and since the questionnaire was not restricted to the mailing lists, it was not possible to estimate a sample calculation. Thus, we obtained a non-probabilistic convenience sample composed of 248 nurses who answered the questionnaire.

We included nurses with at least three months of professional experience in surgical center and who were working in this sector at the time of the study. These inclusion criteria were informed to the participants at the time of the invitation to respond to the online questionnaire. Questionnaires with incomplete and duplicate information were excluded, that is, when the same participant answered the questionnaire more than once. Duplication of answers was assessed by auditing participants' e-mail records, and the last response received was included.

The data collection instrument was composed of two parts, namely: a characterization form with variables about the socio-professional profile of the nurses (gender, age, experience in surgical center, training, country region, type of institution where they worked, weekly workload, type of professional performance and information about the work, such as the number of surgical rooms under the nurse's responsibility and number of surgeries).

In the second part, a questionnaire was drawn up in which participants indicated their level of agreement regarding the fulfillment of each of the 10 objectives of the Safe Surgery Saves Lives Initiative in their current workplace. For the response, a Likert type scale was used with five response options: I Totally Disagree (TD), I Partially Disagree (PD), Neutral (N), I Partially Agree (PA) and I Totally Agree (TA). The 10 goals of the Safe Surgery Saves Lives Initiative(1) are: (1) The team will operate on the correct patient the correct site; (2) The team will use methods known to prevent harm from administration and anesthetics, while protecting the patient from pain; (3)
The team will recognize and effectively prepare for lifethreatening loss of airway or respiratory function; (4) The team will recognize and effectively prepare for risk of high blood loss; (5) The team will avoid inducing an allergic or adverse drug reaction for which the patient is known to be at significant risk; (6) The team will consistently use methods known to minimize the risk for surgical site infection; (7) The team will prevent inadvertent retention of instrumentals or sponges in the surgical wounds; (8) The team will secure and accurately identify all surgical specimens; (9) The team will effectively communicate and exchange critical information for the safe conduct of the operation; and (10) Hospitals and public health systems will establish routine surveillance of surgical capacity, volume and results.

Before data collection, face and content validity was performed with three nurses from a surgical center and two nurse professors with experience in the study theme, who were not included in the study. In addition, the judges performed a pre-test to ascertain the ease/ difficulty in completing the instrument. As there were no disagreements, suggestions and difficulties in filling it out, no changes were required in the instrument.

The data were organized in a spreadsheet and the analysis was done with the use of Statistical Package for Social Sciences (SPSS) for Windows, version 19. The categorical variables were evaluated by means of absolute frequency and percentage. For the continuous variables, the position (mean, minimum and maximum) and dispersion (standard deviation) measurements were analyzed. In order to analyze the adherence of professionals to the objectives of the Initiative, a percentage of agreement equal or superior to $75 \%$ was set as adequate(7).

The ethical recommendations were followed and the research was approved by the Research Ethics Committee through Certificate of Presentation for Ethical Appreciation (CAAE) no. 64255317.9.0000.0121. The Informed Consent Form was presented online to the participants before starting the data collection, in a clarification page about the research. The participant had to click at the option "I agree to participate in the survey" to confirm their agreement to the study terms and be directed to the next screen with the questionnaire.

\section{Results}

A total of 248 responses were received, but the responses of 220 nurses were considered for the study sample. Based on the inclusion and exclusion criteria, we excluded 10 participants who reported having less 
than three months of experience in surgical center, 10 questionnaires due to double participation, and eight due to incomplete items. Table 1 shows the characterization of the socio-professional profile of the sample.

Table 2 shows the distribution of responses regarding adherence to the 10 objectives of Safe Surgery
Saves Lives Initiative. The highest level of agreement was evidenced in objective 1, with 144 (65.5\%) respondents fully and 52 (23.6\%) partially agreeing with it. The lowest percentage of total ( $n=69,31.4 \%$ ) and partial $(n=81 ; 36.8 \%)$ agreement was recorded in objective 10 .

Table 1 - Characterization of the socio-professional profile of the nurses participating in the study. Florianópolis, SC, Brazil, 2017

\begin{tabular}{|c|c|c|c|c|}
\hline Variable & $n(\%)$ & Mean & $\begin{array}{l}\text { Standard } \\
\text { deviation }\end{array}$ & $\begin{array}{l}\text { Variation } \\
\text { (min.-max.) }\end{array}$ \\
\hline Age (years) & & 37.6 & 8.4 & $21-62$ \\
\hline \multicolumn{5}{|l|}{ Sex } \\
\hline Female & 186(84.5) & & & \\
\hline Male & $34(15.5)$ & & & \\
\hline Experience in surgical center (years) & & 7.6 & 7 & $0.25-37$ \\
\hline \multicolumn{5}{|l|}{ Training } \\
\hline Undergraduate course & $31(14.2)$ & & & \\
\hline Specialized in surgical center & $75(34.2)$ & & & \\
\hline Specialization in another area & $62(28.3)$ & & & \\
\hline Master & $39(17.8)$ & & & \\
\hline Phd & $12(5.5)$ & & & \\
\hline \multicolumn{5}{|l|}{ Region } \\
\hline North & $12(5.5)$ & & & \\
\hline Northeast & $29(13.2)$ & & & \\
\hline Central-West and Federal District & $9(4.1)$ & & & \\
\hline Southeast & $86(39.1)$ & & & \\
\hline South & $84(38.2)$ & & & \\
\hline \multicolumn{5}{|l|}{ Type of institution } \\
\hline Private & $86(39.1)$ & & & \\
\hline Public & $76(34.5)$ & & & \\
\hline Philanthropic & $34(15.5)$ & & & \\
\hline Public-Private & $24(10.9)$ & & & \\
\hline \multicolumn{5}{|l|}{ Area of performance } \\
\hline Only CC* & $16(7.3)$ & & & \\
\hline Only PAR ${ }^{\dagger}$ & $6(2.7)$ & & & \\
\hline $\mathrm{SC}^{*}$ and $\mathrm{PAR}^{\dagger}$ & $60(27.3)$ & & & \\
\hline $\mathrm{SC}^{*}, \mathrm{PAR}^{\dagger}$ and $\mathrm{MSC}^{\ddagger}$ & $86(39.1)$ & & & \\
\hline $\mathrm{SC}^{*}$ and another unit & $52(23.6)$ & & & \\
\hline Surgical rooms under their responsibility & & 6 & 3.9 & $0-28$ \\
\hline Average volume of surgeries per month & & 468.79 & 482.9 & $6-3000$ \\
\hline \multicolumn{5}{|l|}{ Type of professional performance } \\
\hline Care nurse & $117(53.2)$ & & & \\
\hline Manager nurse & $103(46.8)$ & & & \\
\hline Weekly workload (in hours) & & 36.6 & 9.1 & $8-60$ \\
\hline
\end{tabular}


Table 2 - Distribution of participants' answers regarding adherence to the 10 objectives of Safe Surgery Saves Lives Initiative. Florianópolis, SC, Brazil, 2017

\begin{tabular}{|c|c|c|c|c|c|}
\hline Objective & $\begin{array}{l}\text { TD* } \\
\mathrm{n}(\%)\end{array}$ & $\begin{array}{l}\mathrm{PD}^{\dagger} \\
\mathrm{n}(\%)\end{array}$ & $\begin{array}{c}N^{\ddagger} \\
n(\%)\end{array}$ & $\begin{array}{l}\mathrm{PA}^{\S} \\
\mathrm{n}(\%)\end{array}$ & $\begin{array}{l}\text { TAll }^{\|} \\
\mathrm{n}(\%)\end{array}$ \\
\hline 1 - The team will operate on the correct patient the correct site & $6(2.7)$ & $10(4.5)$ & $8(3.6)$ & $52(23.6)$ & 144(65.5) \\
\hline $\begin{array}{l}2 \text { - The team will use methods known to prevent harm from administration and } \\
\text { anesthetics, while protecting the patient from pain }\end{array}$ & $8(3.6)$ & $12(5.5)$ & $20(9.1)$ & $64(29.1)$ & 116(52.7) \\
\hline $\begin{array}{l}3 \text { - The team will recognize and effectively prepare for life-threatening loss of } \\
\text { airway or respiratory function }\end{array}$ & $6(2.7)$ & $14(6.4)$ & $17(7.7)$ & $65(29.5)$ & 118(53.6) \\
\hline 4 - The team will recognize and effectively prepare for risk of high blood loss & $6(2.7)$ & $15(6.8)$ & $20(9.1)$ & $66(30)$ & $113(51.4)$ \\
\hline $\begin{array}{l}5 \text { - The team will avoid inducing an allergic or adverse drug reaction for which } \\
\text { the patient is known to be at significant risk }\end{array}$ & $5(2.3)$ & $11(5.0)$ & $14(6.4)$ & $73(33.2)$ & $117(53.2)$ \\
\hline $\begin{array}{l}6 \text { - The team will consistently use methods known to minimize the risk for } \\
\text { surgical site infection }\end{array}$ & $6(2.7)$ & $17(7.7)$ & $10(4.5)$ & $74(33.6)$ & $113(51.4)$ \\
\hline $\begin{array}{l}7 \text { - The team will prevent inadvertent retention of instrumentals or sponges in the } \\
\text { surgical wounds }\end{array}$ & $6(2.7)$ & $14(6.4)$ & $14(6.4)$ & $65(29.5)$ & 121(55) \\
\hline 8 - The team will secure and accurately identify all surgical specimens & $5(2.3)$ & $11(5)$ & $18(8.2)$ & $61(27.7)$ & $125(56.8)$ \\
\hline $\begin{array}{l}9 \text { - The team will effectively communicate and exchange critical information for } \\
\text { the safe conduct of the operation }\end{array}$ & $5(2.3)$ & 19(8.6) & $17(7.7)$ & $73(33.2)$ & $106(48.2)$ \\
\hline $\begin{array}{l}10 \text { - Hospitals and public health systems will establish routine surveillance of } \\
\text { surgical capacity, volume and results }\end{array}$ & $13(5.9)$ & $27(12.3)$ & $30(13.6)$ & $69(31.4)$ & 81(36.8) \\
\hline
\end{tabular}

*I Totally Disagree; †I Partially Disagree; ¥Neutral; §I Partially Agree; ||I Totally Agree.

\section{Discussion}

This is the first study that analyzed adherence to the 10 objectives of the Safe Surgery Saves Lives Initiative in surgical centers from the perspective of nurses from different regions of Brazil. Thus, the results contribute both to the production of scientific knowledge about patient safety in a surgical center and to the practice of nurses and managers in this area of care. In addition, the research presents an overview of the socioprofessional characterization of surgical center nurses in Brazil.

The sample of this study was composed mainly by female participants ( $n=186 ; 84.5 \%$ ), with a mean of 37.6 years of age. These results are in line with the sociodemographic profile of nurses in Brazil(9). The majority of participants had a specialization in a surgical center ( $n=75,34.2 \%$ ), worked in a private hospital $(n=86,39.1 \%)$ and were care nurses $(n=117$, $53.2 \%)$.

The number of surgical rooms under the responsibility of nurses ranged from zero to 28 . Despite the importance of nurses in the management of care ${ }^{(10)}$, the response zero may indicate that some have not considered themselves directly responsible for the operating rooms and attribute such responsibility to other nurses or managers.

Most of the answers came from the South and Southeast regions, which may be related to the greater number of hospitals and surgical centers in these places.
In addition, there is a concentration of the number of nurses in large urban centers in Brazil(9).

Most nurses worked in more than one unit in the institution, in addition to the Surgical Center ( $n=138$; $62.7 \%)$, mainly Post-Anesthesia Recovery and Material and Sterilization Center ( $n=86 ; 39.1 \%)$. In this sense, working in more than one sector can negatively impact nurses' control over the care environment ${ }^{(11)}$.

Regarding adherence to the 10 objectives of the Safe Surgery Saves Lives Initiative, with the exception of objective 10 , the other objectives presented partial and total agreement rates above $75 \%$. This result indicates an adequate level of adherence to nine of the 10 analyzed objectives( ${ }^{(7)}$.

However, some serious adverse events related to surgical procedures should not occur. These are never events, such as surgery or other invasive procedure performed at the wrong site or wrong patient; wrong surgery or invasive procedure in a patient; unintentional retention of foreign body in a patient after surgery or invasive procedure; and intraoperative or immediately postoperative death of a patient, according to the classification of the American Society of Anesthesiology $(\text { ASA })^{(12-13)}$.

From this classification, it can be considered that objectives 1, 7 and 8 aim at the prevention of never events. Therefore, any option other than I Totally Agree (TA) indicated by the participants of this study regarding these objectives indicates a risk to patient safety. 
According to ANVISA, in Brazil, from 2014 to 2017, 19 intraoperative or immediately postoperative deaths occurred in ASA I patients, 66 reports of unintentional foreign body retention and 12 surgical procedures in the wrong site of the body ${ }^{(13)}$.

Similarly, a Brazilian study identified a $98 \%$ rate of adherence of the team in relation to the 10 goals proposed by the WHO through the checklist of safe surgery. However, many items were not adequately filled, evidencing failure in patient safety, especially in objectives $1,4,5,7,8$ and $9^{(14)}$.

In the international context, Canadian researchers, analyzing 212 cases of patients submitted to emergency abdominal surgery, found that $51.9 \%$ had a non-fatal complication, $22.6 \%$ lost independence and $6.6 \%$ died at the hospital(15). In the Netherlands, from the investigation of 67,630 surgical procedures, 2,563 incidents were identified, of which 34\% $(n=877)$ resulted from non-compliance with institutional protocols by professionals(16).

The following is a discussion of the results obtained by each of the 10 objectives of the Safe Surgery Saves Lives Initiative.

Objective 1 obtained the highest agreement rate $(89.1 \%)$ in relation to the objectives analyzed. However, this result is worrying, as this objective refers to a never ending event. A study conducted in São Paulo, Brazil, showed that $55 \%$ of the nursing staff classified the absence of laterality as an adverse event(17). A survey conducted with 502 Brazilian orthopedists showed that $40 \%$ reported not demarcating the surgery site and $40 \%$ said they had already performed surgery in the wrong place. Most of the participants reported never being trained to use the safe surgery protocol(18). Although it is not a reality in Brazil, the demarcation of the surgical site by nurses can contribute to the safety of the surgery according to Swiss study results(19).

Regarding Objectives 2, 3, 4 and 5, on average, $50 \%$ of participants reported fully agreeing that the team adheres to WHO recommendations. These four objectives refer to patient safety in the anesthetic procedure(1), which may have contributed to similar levels of agreement between participants.

The pre-anesthetic consultation should be performed for patients submitted to elective procedures and enables the prevention of events related to anesthetic practices. It is important for risk assessment for difficult airways, identification of allergies or adverse reactions and prediction of possible blood loss during the surgical procedure ${ }^{(20)}$.
Difficult airway access generates complications that can result in death or brain damage, which are avoidable from the assessment of the airway before anesthetic induction ${ }^{(21)}$. In Brazil, there are technologies available for the prevention of difficult airways, including simple and economical alternatives that contribute to patient safety ${ }^{(22)}$

The prevention of risks related to adverse events is a key point in the safety of the anesthetic act. A Brazilian study presented an overview of the occurrence of Perioperative Anaphylaxis (PEOA), which is a rare allergic reaction, but with a rapid and fatal onset. The incidence varies according to the country, being $1: 1,250$ to $1: 13,000$ surgeries. The main causes are muscle relaxants, latex and antibiotics ${ }^{(23)}$.

Approximately $15 \%$ to $40 \%$ of patients who undergo surgical procedures present anemia at the time of surgery ${ }^{(24)}$. From the pre-anesthetic consultation, it is possible to reverse the anemic condition of the patient in about 15 days. Preoperative anemia is directly related to blood transfusion in the surgical procedure, which is considered the main cause of postoperative morbidity and mortality(25).

Another important aspect is the role of the anesthesiologist in the administration of anesthetic drugs. Although intravenous drug delivery protocols have not shown major changes in the last 60 years, there is still a high rate of errors related to medication in the anesthetic act(26).

In Santa Catarina, Brazil, a study with 61 anesthetists showed that $91.8 \%$ had already committed more than one medication administration error. The main causes were distraction, fatigue or low severity of the patient(27). In China, a study showed omission, incorrect dosage and medication substitutions as major causes of error in anesthetic medication ${ }^{(28)}$. Incorrect identification of ampules and syringes is also one of the main causes of medication error related to the anesthetic act(29).

In view of the international scenario and the legislation in force in Brazil, the work of the nurse combined with the anesthesiologist is crucial in for the planning and organization of materials and equipment for the anesthetic procedure. In addition, in the United States and in some European countries, there is a legislation that defines the training and independent performance of the nurse, with care protocols that allow the elaboration of the anesthetic plan and autonomy for the execution of care during the surgical procedure(6)

Objective 6 obtained $85 \%$ of agreement among the nurses. Surgical Site Infection (SSI) occurs in about 3\% to $20 \%$ of surgical procedures, constituting the main 
cause of morbidity and mortality in modern medical care $^{(30)}$. Most SSIs are preventable, especially from the conduction of prophylactic antibiotic ${ }^{(31-32)}$. In Brazil, the adherence rate to the use of prophylactic antibiotic therapy is $84 \%{ }^{(33)}$. In Sweden, this rate is estimated at $92 \%{ }^{(34)}$.

Objective 7 had an agreement rate of $84 \%$ and also referred to a never event. This result is worrying given the serious consequences of such an event on patients. Sponge counting is a low-cost practice that requires organization and a structured method, such as a printed form ${ }^{(1,35)}$. Retention of a sponge on a surgical wound generates a gossypiboma, which is a textile matrix wrapped by foreign body reaction. It occurs mainly in the intra-abdominal area and may present fistula, abscess or mass ${ }^{(36)}$.

The incidence of gossypiboma is underreported due to medical and legal implications. According to a literature review, its occurrence rate in abdominal operations is $1: 1,000$ to $1: 1,500$. The patient often becomes asymptomatic, which also contributes to underreporting ${ }^{(37)}$. A study carried out in Pakistan has shown that the occurrence of gossypiboma occurs mainly in emergency surgeries ${ }^{(38)}$.

In Objective 8 , partial and total agreement rate was of $84.5 \%$. This finding is in line with the results of a study with 31 nursing professionals from a surgical center in São Paulo, Brazil, of which $92.9 \%$ considered the inappropriate disposal of a surgical specimen a serious adverse event(15). In Taiwan, of the 200,345 specimens collected at a medical center, 1023 were with misidentification ${ }^{(39)}$.

Objective 9 obtained $81.4 \%$ of agreement, the second lowest index among the evaluated objectives, indicating that communication problems are very frequent in a surgical center. A Dutch study associated $11 \%$ of adverse events occurred in the operating room with relationship problems and communication failures $^{(14)}$. In Brazil, the lack of communication between the medical and nursing staff represents $32 \%$ of the causes of adverse events in a surgical center ${ }^{(15)}$.

Objective 10 presented the lowest level of agreement among the analyzed objectives. The sharing of information and the socialization of indicators encourages learning from error. In addition, ongoing notification and tracking strengthens the dissemination of the safety culture and engages team members in the development of best safety practices ${ }^{(33)}$. The monitoring of results in the surgical centers is important to enable managers and professionals for decision making in the surgical center ${ }^{(40)}$.
Thus, the results of the present study contribute to evidence of the complexity of adherence to WHO recommendations in the Safe Surgery Saves Lives Initiative. In addition, the findings may help managers and health professionals in the development of strategies for patient safety in the surgical center, especially in relation to never events.

Regarding the limitations of this study, the interpretations of the results can be considered of restricted scope due to the cross-sectional cut of the research and to the adoption of a non-probabilistic convenience sample. It should be emphasized that this kind of sampling does not allow us to identify whether the selected people are really representative of the population.

However, the characteristics of the sample of the present study can help in the estimation of sample numbers for future studies, since it was a large population, with a significant number from several Brazilian regions. In relation to internal validity, performing online data collection makes it difficult to control samples and populations, since the questionnaire can be completed by someone other than the professional. In addition, it is easier for the participant to refuse to participate or to leave the study in progress, as well as there is greater possibility of people interested in the subject to cross the composition of the sample.

\section{Conclusion}

Appropriate adherence to nine of the 10 objectives of the Safe Surgery Saves Lives Initiative was found. The objective that presented unsatisfactory adherence concerns the adoption by hospitals and health systems of routine surveillance mechanisms on surgical capacity, volume and results. Thus, it is expected that this study may subsidize the discussion of strategies to increase patient safety in the surgical center, especially in relation to health surveillance and prevention of never events.

\section{References}

1. Organização Mundial da Saúde. Segundo desafio global para a segurança do paciente: cirurgias seguras salvam vidas [Internet]. Rio de Janeiro: Organização Pan-Americana da Saúde/Ministério da Saúde/Agência Nacional de Vigilância Sanitária; 2009. [Acesso 18 mar 2018]. Disponível em: http://bvsms.saude.gov.br/ bvs/publicacoes/seguranca_paciente_cirurgia_salva_ manual.pdf

2. Carvalho PA, Göttems LBD, Pires MRGM, Oliveira MLC. Safety culture in the operating room of a public 
hospital in the perception of healthcare professionals. Rev. Latino-Am. Enfermagem [Internet]. 2015 [cited Feb 4, 2018];23(6):1041-8. Available from: http://www. scielo.br/scielo.php?script =sci_arttext\&pid=S0104$11692015000601041 \&$ lng =pt\&nrm=iso\&tIng=en

3. Corona ARP, Peniche ACG. The patient safety culture in the adherence to the safe surgery protocol. Rev SOBECC. [Internet]. 2015 [cited Feb 4, 2018];20(3):179-85. Available from: https://revista.sobecc.org.br/sobecc/ article/view/88/pdf_1

4. Campione J, Famolaro T. Promising practices for improving hospital patient safety culture. Jt Comm J Qual Patient Saf. [Internet]. 2018 [cited Feb 4, 2018];44(1):23-32. Available from: https://www.ncbi. nlm.nih.gov/pubmed/29290243

5. Lemos CS, Peniche ACG. Nursing care in the anesthetic procedure: an integrative review. Rev Esc Enferm USP. [Internet]. 2016 [cited Feb 4, 2018];50(1):158-66. Available from: http://www. scielo.br/scielo.php?script $=$ sci_arttext $\&$ pid $=$ S0080$62342016000100154 \& \operatorname{lng}=e n \& n r m=i s o \& t$ Ing $=e n \& O R I$ GINALLANG $=$ en

6. Silva ACA, Silva JF, Santos LRO, Avelino AVSD, Santos AMR, Pereira AFM. Patient safety in the hospital context: an integrative literature review. Cogitare Enferm. [Internet]. 2016 [cited Feb 4, 2018];21(1):1-9. Available from: http://revistas.ufpr.br/cogitare/article/ view/37763/pdf_1

7. Sax H, Perneger T, Hugonnet S, Herrault P, Chraiti MN, Pittet D. Knowledge of standard and isolation precautions in a large teaching hospital. Infect Control Hosp Epidemiol. [Internet]. 2005 [cited Aug 20, 2018];26:298-304. Available from: https://www.ncbi. nlm.nih.gov/pubmed/15796284

8. Faleiros F, Käppler C, Pontes FAR, Silva SSC, Goes FSN, Cucick CD. Use of virtual questionnaire and dissemination as a data collection strategy in scientific studies. Texto Contexto Enferm. [Internet]. 2016 [cited Feb 4, 2018];25(4):e3880014. Available from: http://www.scielo.br/scielo.php?script=sci_arttext\&pid $=$ S0104-07072016000400304

9. Machado MH, Aguiar W, Filho, Lacerda WF, Oliveira E, Lemos $W$, et al. Características gerais da enfermagem: o perfil sócio demográfico. Enferm Foco. [Internet]. 2016 [Acesso 4 fev 2018];7(esp):9-14. Disponível em: http:// revista.portalcofen.gov.br/index.php.

10. Mororó DDS, Enders BC, Lira ALBC, Silva CMB, Menezes RMP. Concept analysis of nursing care management in the hospital context. Acta Paul Enferm. [Internet]. 2017 [cited Feb 4, 2018];30(3):32332. Available from: http://www.scielo.br/scielo. php?pid $=$ S0103-21002017000300323\&script $=$ sci_ arttext\&tIng=en

11. Toffoletto MC, Ruiz XR. Improving patient safety: how and whyincidences occur in nursing care. Rev Esc Enferm USP. [Internet]. 2013 [cited Feb 4, 2018];47(5):1098105. Available from: http://www.scielo.br/pdf/reeusp/ v47n5/0080-6234-reeusp-47-05-1098.pdf

12. Bolton H. Never Events - the ongoing problem of the retained vaginal sponge/swab. BJOG: Int J Obstet Gynecol. [Internet]. 2017 [cited Feb 4, 2018];124:1422. Available from: https://obgyn.onlinelibrary.wiley.com/ doi/pdf/10.1111/1471-0528.14041

13. Agência Nacional de Vigilância Sanitária. Relatórios reúnem os dados, por Estado, de Eventos adversos notificados à Anvisa no período de Janeiro de 2014 a Julho de 2017 Brasília: Anvisa. [Internet]. 2017 [Acesso 4 fev 2018]. Disponível em: https://www20.anvisa. gov.br/segurancadopaciente/index.php/publicacoes/ category/relatorios-dos-estados

14. Amaya MR, Maziero ECS, Grittem L, Cruz EDA. Adherence to the use of the surgical checklist for patient safety. Esc Anna Nery. [Internet]. 2015 [cited Feb 4, 2018];19(2):246-51. Available from: http:// www.scielo.br/scielo.php?script =sci_arttext\&pid $=$ S1983-14472015000400014

15. Bailey JG, Davis PJB, Levy AR, Molinari M, Johnson PM. The impact of adverse events on health care costs for older adults undergoing nonelective abdominal surgery. Can J Surg [Internet]. 2016 [cited Jan 5, 2018];59(3):172-9. Available from: https://www.ncbi. nlm.nih.gov/pubmed/26999476

16. Chevalking AJH, Calsbeek H, Damen J, Gooszen H. Wolff AP. The impact of a standardized incident reporting system in the perioperative setting: a single center experience on 2,563 "near-misses" and adverse events. Patient Saf Surg. [Internet]. 2014 [cited Jan 5, 2018];8:46. Available from: https://www.ncbi.nlm.nih. gov/pubmed/25632301

17. Bohomol E, Tartali JA. Adverse effects in surgical patients: knowledge of the nursing professionals. Acta Paul Enferm. [Internet]. 2013 [cited Jan 5, 2018];26(4):376-81. Available from: http://www.scielo.br/scielo.php?pid=S010321002013000400012\&script=sci_arttext\&tIng=en

18. Filho GRM, Silva LFN, Ferracini AM, Bähr GL. The WHO Surgical Safety Checklist: knowledge and use by Brazilian orthopedists. Rev Bras Ortop. [Internet]. 2013 [cited Jan 5, 2018];48(6):554-62. Available from: http://www.scielo.br/scielo.php?script=sci_ arttext\&pid=S0102-36162013000600554\&lng=en\&nrm $=$ iso\&tlng $=e n$ 
19. Thurnherr JS, Biegger A, Soll C, Melcher GA. Should nurses be allowed to perform the pre-operative surgical site marking instead of surgeons? A prospective feasibility study at a Swiss primary care teaching hospital. Pat Saf Surg. [Internet]. 2017 [cited Jan 5, 2018];11:9. Available from: https://www.ncbi.nlm.nih. gov/pmc/articles/PMC5379652/

20. Schwartzman UP, Batista KT, Duarte LTD, Saraiva RÂ, Fernandes MCBC, Costa VV, et al. Anesthetic complications in a rehabilitation hospital: is the incidence related to the pre-anesthetic visit?. Braz J Anesthesiol. [Internet]. 2014 [cited Jan 5, 2018];64(5):357-64. Available from: https://www.sciencedirect.com/science/ article/pii/S0104001414000360

21. Apfelbaum JL, Hagberg CA, Caplan RA, Blitt CD, Connis RT, Nickinovich DG, et al. Practice Guidelines for Management of the Difficult Airway: An Updated Report by the American Society of Anesthesiologists Task Force on Management of the Difficult Airway. Anesthesiology. [Internet]. 2013 [cited Jan 5, 2018];118:25170. Available from: https://www.ncbi.nlm.nih.gov/ pubmed/23364566

22. Neto FLD, Andrade JMS, Raupp ACT, Townsend RS, Neres FS, Cremonese RV. Use of a homemade introducer guide (bougie) for intubation in emergency situation in patients who present with difficult airway: a case series. Braz J Anesthesiol. [Internet]. 2016 [cited Jan 05, 2018];66(2):204-7. Available from: https://www.sciencedirect.com/science/article/pii/ S0034709414000294?via\%3Dihub

23. Aun VM, Garro LS, Ribeiro MR, Motta AA, Kalil J, Bianchi PG. Perioperative anaphylaxis: The brazilian experience. Rev Port Imunoalergol. [Internet]. 2016 [citado Fev 4, 2018];24(2):99-106. Available from: http://www.scielo.mec.pt/scielo.php?pid=S0871$97212016000200006 \&$ script=sci_arttext\&tlng=en. ISSN 0871-9721

24. Spahn DR, Goodnough LT. Alternatives to blood transfusion. Lancet. [Internet]. 2013 [cited Feb 4, 2018];381:1789-876. Available from: https://wwwsciencedirect-com.ez46.periodicos.capes.gov.br/science/ article/pii/S0140673613608089

25. Obi AT, Park Y], Bove P, Cuff R, Kazmers A, Gutm HS, et al. The association of perioperative transfusion with 30-day morbidity and mortality in patients undergoing major vascular surgery. J Vasc Surg. [Internet]. 2014 [cited Jan 5, 2018];61(4):1000-9.e1. Available from: https://www.ncbi.nlm.nih.gov/pubmed/25596978

26. Dhawan I, Tewari A, Sehgal S, Sinha AC. Medication errors in anesthesia: unacceptable or unavoidable? Rev Bras Anestesiol. [Internet]. 2017 [cited Jan 5,
2018];67(2):184-92. Available from: https://www.ncbi. nlm.nih.gov/pubmed/28236867

27. Erdmann TR, Garcia JHS, Loureiro ML, Monteiro MP, Brunharo GM. Profile of drug administration errors in anesthesia among anesthesiologists from Santa Catarina. Braz J Anesthesiol. [Internet]. 2016 [cited Jan 5, 2018];66(1):105-10. Available from: https://www.sciencedirect.com/science/article/pii/ S0034709414001950

28. Zhang Y, Dong YJ, Webster CS, Ding XD, Liu SY, Chen WM, et al. The frequency and nature of drug administration error during anaesthesia in a Chinese hospital. Acta Anaesthesiol Scand. [Internet]. 2013 [cited Jan 5, 2018];57(2):158-64. Available from: https://www.ncbi.nlm.nih.gov/pubmed/22946731

29. Orser AB, Hyland S, U D, Sheppard I, Wilson CR. Review article: Improving drug safety for patients undergoing anesthesia and surgery. Can J Anesth. [Internet]. 2013 [cited Jan 5, 2018];60:127. Available from: https://www.ncbi.nlm.nih.gov/ pubmed/23264011

30. Garner BH, Anderson DJ. Surgical Site Infection: An Update. Infect Dis Clin North Am. [Internet]. 2016 [cited Jan 5, 2018];30(4):909-29. Available from: https:// www.ncbi.nlm.nih.gov/pubmed/27816143

31. Medeiros AC, Carvalho MDF. Infection in surgery. J Surg Cl Res [Internet]. 2016 [cited Jan 5, 2018];7(2)6073. Available from: https://periodicos.ufrn.br/jscr/ article/view/11413

32. Santos GC, Baylão AFG, Borges SCF, Silva LA, Batista $M H J$, Leite GR. Incidence and risk factors of surgical wound infection: integrative literature review. Itinerarius Reflectionis. [Internet]. 2015 [cited Mar 5, 2018];11(1):1-15 Available from: http://repositorio. bc.ufg.br/handle/ri/11058

33. Bezerra WR, Bezerra ALQ, Paranagua TTB, Bernardes MJC, Teixeira CC. Occurrence of incidents at a surgical center: a documentary study. Rev Eletr Enferm. [Internet]. 2015 [cited Jan 5, 2018];17(4):110. Available from: https://revistas.ufg.br/fen/article/ view/33339/20690

34. Rydenfält C, Johansson G, Odenrick P, Akerman $K$, Larsson PA. Compliance with the WHO Surgical Safety Checklist: deviations and possible improvements. Int J Q Health Care. [Internet]. 2013 [cited Jan 5, 2018];25(2):182-7. Available from: https://www.ncbi. nlm.nih.gov/pubmed/23335056

35. Freitas OS, Mendes KDS, Galvão CM. Surgical count process: evidence for patient safety. Rev Gaúcha Enferm. [Internet]. 2016 [cited Jan 5, 2018];37(4):e66877. Available from: http://www.scielo.br/scielo. 
php pid $=$ S1983 $-14472016000400418 \&$ script $=$ sci arttext\&tlng=en

36. Ranjan R, Nityasha N, Anubhav P, Arya K, Mishra $N$. Transvisceral migration of gossypiboma presenting as gastric outlet obstruction managed endoscopically. Int Surg J. [Internet]. 2016 [cited Jan 5, 2018];3(3):16635. Available from: http://www.ijsurgery.com/index.php/ isj/article/view/348

37. Silva SM, Sousa JB. Gossypiboma after abdominal surgery is a challenging clinical problem and a serious medicolegal issue. Arq Bras Cir Dig. [Internet]. 2013 [cited Jan 5, 2018];26(2):140-3. Available from: http://www.scielo.br/scielo.php?script=sci_ arttext\&pid=S0102-67202013000200015\&lng=en\&nrm $=$ iso\&tlng $=e n$

38. Naeem M, Ahmad M, Samad A, Haq I. Gossypiboma: A medical negligence. Pak J Surg. [Internet]. 2017. [cited Feb 4, 2018];33(1):83-6. Available from: http:// www.pjs.com.pk/journal_pdfs/jan_mar17/83.pdf 39. Ning $\mathrm{CH}$, Lin CN, Chiu DTY, Chang YT, Wen CN, Peng $\mathrm{SY}$, et al. Reduction in Hospital-Wide Clinical Laboratory Specimen Identification Errors following Process Interventions: A 10-Year Retrospective Observational Study. PLoS ONE. [Internet]. 2016 [cited Jan 5, 2018];11(8):e0160821. Available from: https://www. ncbi.nlm.nih.gov/pubmed/27494020

40. Silva EFM, Calil ASG, Araújo CS, Ruiz PBO, Jericó MC. Conhecimento dos profissionais da saúde sobre checklist de cirurgia segura. Arq Ciênc Saúde. [Internet]. 2017 [cited Jan 5, 2018];24(3):71-8. Available from: http://www.cienciasdasaude.famerp.br/index.php/racs/ article/view/731 Creative Commons (CC BY).

This license lets others distribute, remix, tweak, and build upon your work, even commercially, as long as they credit you for the original creation. This is the most accommodating of licenses offered. Recommended for maximum dissemination and use of licensed materials. 